\title{
Can Recent traces help in recognising probable jellyfish remains from the Muschelkalk of Winterswijk? A comment
}

\section{G.C. Cadée}

NI0Z Koninklijk Nederlands Instituut voor Onderzoek der Zee, Postbus 59, 1790 AB Den Burg, the Netherlands. Email: gerhard.cadee@nioz.nl

Manuscript received: May 2013, accepted: September 2013

\section{Abstract}

A possible other explanation is given for one of the probably jellyfish remains published by 0osterink \& Winkelhorst in this Journal. Comparison with Recent traces suggests one (fig. 12) might be a 'scribe mark'.

\section{Comment}

Oosterink \& Winkelhorst (2013) published a wonderful paper on hitherto unknown (probably) jellyfish fossils from the famous Lower Middle Triassic Muschelkalk quarries near Winterswijk, eastern Netherlands.

They cite the few earlier papers on Mesozoic Medusa, but I missed references to Recent traces and (experimental) work on taphonomy of Medusae such as Schäfer (1941, 1962) and Hertweck (1966). Both authors conclude that imprints of Medusae can be left in tidal flat sediments that remain dry for part of the tidal cycle. Already Walcott (1898) made imprints of recent medusa in plaster. I include here a picture I made on the tidal flat in the Mokbaai on Texel (Fig.1). Medusae consist for some $98 \%$ of water, so little remains if they dry out. Moreover part of their liquid will be consumed by Diptera (Fig. 2). Nevertheless, still a recognisable imprint can remain if it is in time covered by a new layer of fine sediment in a tidal environment. Oosterink \& Winkelhorst suggest indeed a tidal environment for their jellyfish remains.

It is their last picture (fig. 12) which differs from the rest in showing clearly concentric circles which are absent in their other jellyfishes. For this one I would suggest another probable origin. Such traces with concentric circles are well known in Recent coastal environments and produced e.g. by Marram grass (Ammophila arenaria) leaf tips in dune sand and called scribe marks in Pilkey et al. (2011). Often they are only part of a circle, but sometimes entire circles are produced. Fig. 3 gives one I found on the coast of Texel produced by a root of Marram

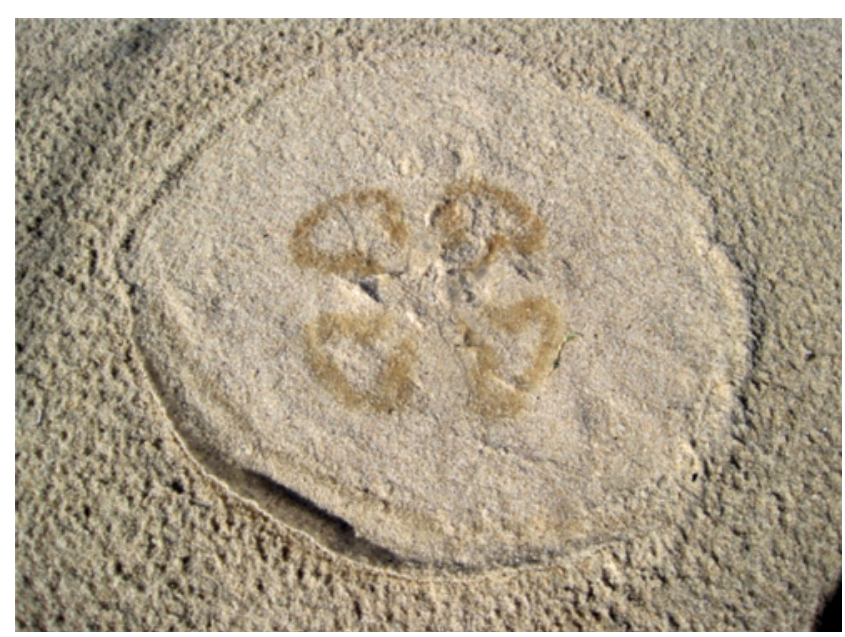

Fig. 1. Impression of Aurelia aurita high on tidal flat Mokbaai Texel 5.5.2010.

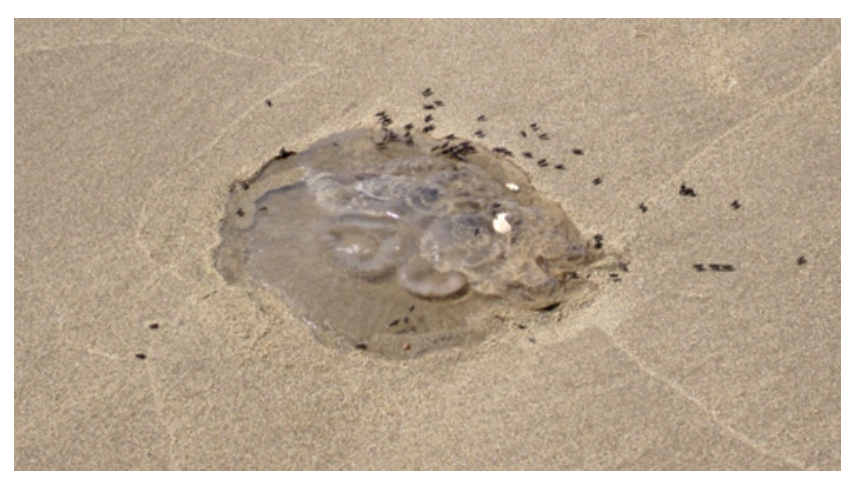

Fig. 2. Recently beached Aurelia aurita with feeding beach flies, North Sea Beach Texel 28.5.2013. 


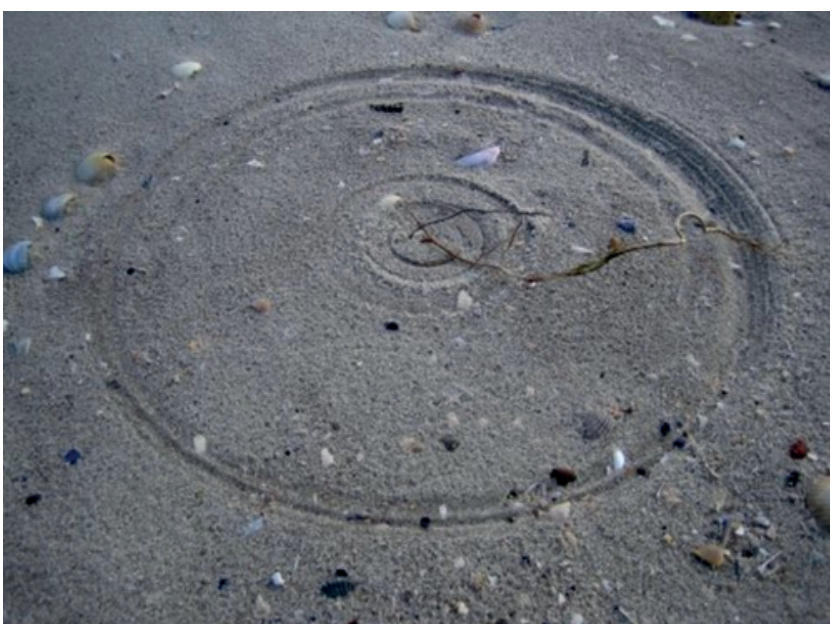

Fig 3. Scribe mark made by Marram grass root North Sea Beach Texel, 27.11.2007.

grass fixed in the middle of the circle and moved around by the wind. Would it be possible that 0osterink \& Winkelhorst's fig. 12 was produced in a similar way by something, now disappeared, that was circling around the center? This would explain the concentric circles which I think are not present in a medusa imprint.

\section{References}

Hertweck, G., 1966. Möglichkeiten des Fossilwerdens von Quallen - im Experiment. Natur und Museum 96: 456-462.

Oosterink, H.W. \& Winkelhorst, H., 2013. Probable remains of jellyfish (Cnidaria, Scyphozoa) from the Lower Middel Triassic (Anisian) of Winterswijk, eastern Netherlands. Netherlands Journal of Geosciences 92(1): 61-67.

Pilkey, 0.H., Neal, W.J., Kedlley, J.T. \& Cooper J.A.G., 2011. The World's Beaches. A global guide to the science of the shoreline. University of California Press (Berkeley), $283 \mathrm{pp.}$

Schäfer, W., 1941. Fossilisations-Bedingungen von Quallen und Laichen. Senckenbergiana 23: 189-216.

Schäfer, W., 1962. Aktuo-Paläontologie nach Studien in der Nordsee. W. Kramer (Frankfurt am Main), $666 \mathrm{pp.}$

Walcott, C.D., 1898. Fossil Medusae. Monographs of the United States Geological Survey 30: 1-201. 